\title{
PENATALAKSANAAN PENYAKIT INFEKSI SALURAN PERNAFASAN AKUT PADA BALITA DENGAN PENDEKATAN MANAJEMEN TERPADU BALITA SAKIT (MTBS)
}

\author{
Muslimin*
}

\begin{abstract}
ABSTRAK
Tingginya angka kesakitan penyakit ISPA di Puskesmas Kedawung Kabupaten Cirebon dan mengalami kenaikan yaitu 32\% pada tahun 2008 dan 36,5\% pada tahun 2009, rendahnya cakupan penemuan kasus pneumonia dan terdapatnya 3 kematian balita akibat infeksi sistem pernafasan padahal Puskesmas Kedawung Kabupaten Cirebon sudah menerapkan pendekatan MTBS (Manajemen Terpadu Balita Sakit) sejak tahun 2002. Penelitian ini bertujuan mendapatkan gambaran tentang penatalaksanaan penyakit ISPA pada balita dengan pendekatan MTBS di Puskesmas Kedawung Kabupaten Cirebon tahun 2013. Metode penelitian deskripsi dengan menggunakan instrumen penelitian lembar pengamatan daftar tilik. Jumlah sampel adalah 65 kegiatan penatalaksanaan penyakit ISPA pada balita yang dilakukan oleh 5 orang petugas yang bertugas di ruang MTBS Puskesmas Kedawung Kabupaten Cirebon. Teknik pengambilan sampel dengan accidental sampling. Hasil penelitian ini didapatkan bahwa penatalaksanaan penyakit ISPA pada balita dengan pendekatan MTBS di Puskesmas Kedawung Kabupaten Cirebon tahun 2014 kurang baik. Dimana masing-masing sub variabel didapatkan hasil sebagai berikut : menilai penyakit ISPA pada balita $69,2 \%$ baik dan 30,8\% kurang baik; mengklasifikasikan penyakit ISPA pada balita 46,2\% baik dan 53,8\% kurang baik; menentukan tindakan 98,5\% baik dan 1,5\% kurang baik;memberikan pengobatan 56,9\% baik dan 43,1\% kurang baik; konseling terhadap ibu $96,7 \%$ baik dan 3,3\% kurang baik; sedangkan untuk tindak lanjut kasus hanya 5 kasus dari 15 kasus yang seharusnya datang dengan hasil $40 \%$ baik dan $60 \%$ kurang baik.
\end{abstract}

Kata Kunci : Menilai, Mengklasifikasi, Tindakan, Mengobati, Konseling

\begin{abstract}
The high rates of respiratory disease in hospital morbidity and Bradford is increased $32 \%$ in 2008 and $36.5 \%$ in 2009 , the low coverage of the discovery of three cases of pneumonia and the presence of infant mortality due to respiratory system infections when Bradford hospitals already implementing IMCI approach ( Integrated Management Childhood Illness ) since 2002. This study aims to gain an overview of the management of respiratory disease in young children with IMCI approach in Kedawung Hospital District Cirebon in 2013.This research method is the description by using research instruments observation checklist sheet . The number of samples is 65 ARI disease management activities undertaken by toddlers 5 officers who served in the Bradford Hospital IMCI .Sampling techniques with accidental sampling.The results of this study found that the management of respiratory disease in young children with IMCI approach in 2013 Kedawung Hospital District Cirebon unfavorable. Wherein each subvariabel obtained the following results: assessing respiratory disease in young children both $69.2 \%$ and $30.8 \%$ unfavorable ; classify respiratory disease in infants $46.2 \%$ good and $53.8 \%$ unfavorable ; decisive action 98 , both $5 \%$ and $1.5 \%$ unfavorable ; provide better treatment $56.9 \%$ and $43.1 \%$ unfavorable ; counseling for both mothers and $96.7 \%, 3.3 \%$ unfavorable, while to follow up the case only 5 cases of the 15 cases that were supposed to come with $40 \%$ good results and $60 \%$ poor.
\end{abstract}

Keywords : Assess, Classify, Action, Treat, Counseling 


\section{PENDAHULUAN}

Infeksi Saluran Pernafasan Akut (ISPA) merupakan penyebab utama kesakitan dan kematian pada bayi dan anak di Negara berkembang termasuk Indonesia.Setiap tahun dari 15 juta kematian yang diperkirakan terjadi di kalangan usia di bawah lima tahun (balita) kira-kira 4 juta kematian atau 26,6\% disebabkan oleh penyakit ISPA terutama Pneumonia. ${ }^{1}$

Penyakit ISPA (Infeksi Saluran Pernafasan Akut) juga merupakan salah satu penyebab utama kunjungan pasien di sarana kesehatan. ${ }^{1}$ Penyakit ISPA mengganggu pertumbuhan dan perkembangan anak balita karena kejadian penyakit ini pada seorang anak balita dalam setahun bisa 3 kali sehingga akan menghambat kualitas sumber daya manusia Indonesia yang baik dimasa yang akan datang.

Pada tahun 2008 WHO mempublikasikan pola baru tatalaksana penderita ISPA dan pada Lokakarya Nasional III tahun 2007 di Cimacan telah dibahas tatalaksana penderita ISPA pola baru ini. Dalam lokakarya ini disepakati untuk menerapkannya di Indonesia setelah di adaptasi sesuai dengan situasi dan kondisi setempat maka sejak tahun 2007 pemberantasan penyakit ISPA menitik beratkan atau memfokuskan kegiatan pada penanggulangan pneumonia balita dengan klasifikasi penyakit ISPA non pneumonia, pneumonia dan pneumonia berat. ${ }^{1}$

Kejadian ISPA dan pneumonia di Indonesia pada balita diperkirakan antara 40\%-60\% untuk ISPA dan 10\%-20\% untuk pneumonia pertahun. Secara teoritis diperkirakan bahwa $10 \%$ dari penderita pneumonia akan meninggal bila tidak di beri pengobatan dan perawatan baik oleh tenaga kesehatan ataupun oleh keluarga terutama ibu. ${ }^{2}$

Tingginya angka kematian balita akibat pneumonia maka WHO dan Unicef mengembangkan suatu strategi yang disebut Manajemen Terpadu Balita Sakit (MTBS) yang merupakan upaya kuratif sekaligus upaya promotif dan preventif. MTBS dirancang untuk memadukan pendekatan 6 penyakit utama yaitu Pneumonia, Diare, Malaria, Demam Berdarah Dengue, Campak, Penyakit Telinga serta malnutrisi dan anemia pada balitadengan menggunakan algoritma untuk mengklasifikasikan balita sakit yang prinsipnya memperbaiki kualitas pelayanan kesehatan pada balita sakit secara menyeluruh tidak terpisah-pisah antara satu gejaladengan gejala yang lain. ${ }^{2}$

Pendekatan MTBS ini telah dilakukan di Kabupaten Donggala dimulai tahun 2009 dengan ujicoba 4 puskesmas yang hasilnya dapat meningkatkan cakupan penemuan kasus pneumonia dari $69 \%$ pada tahun 2008 menjadi $86 \%$ pad atahun 2009 dan 100,9\% pada tahun 2010. Namun keberhasilan puskesmas dalam pendekatan MTBS belum dapat dievaluasi di tingkat pelaksanaan baikterhadap masalah petugas dan pasien pada tatalaksana standar. ${ }^{1}$

Salah satu upaya dinas kesehatan untuk keberhasilan pemberantasan penyakit ISPA pada balita adalah meningkatkan kualitas tatalaksana penderita ISPA dengan cara meningkatkan pengetahuan, sikap dan perilaku tenaga kesehatan baikdokter, perawat ataupun bidan dalam penatalaksanaan ISPA padabalita yang terintegrasi dalam kegiatan MTBS (Manajemen Terpadu Balita Sakit) yang merupakan suatu pendekatan keterpaduan dalam memberikan pelayanan peningkatan kesehatan, pencegahan penyakit, perawatan dan pengobatan penyakit dalam menangani balita yang sakit serta konseling atau pendidikan kesehatan. ${ }^{2}$

Pemberikan konseling/pendidikan kesehatan meliputi kegiatan petugas kesehatan dalam menjelaskan: tanda bahaya umum, kapan ibu harus kembali membawa balitanya, cara menjaga kesehatan/pencegahan penyakit, cara/anjuran pemberian makan balita serta memberikan pelayanan tindak lanjut. Tindak lanjut pada kasus lama meliputi kegiatan petugas kesehatan dalam menilai ulang kondisi balita yang menderita penyakit ISPA yang telah diberi pengobatan dan perlu tidaknya penggantian antibiotik. ${ }^{2}$ 
Penanganan penyakit ISPA pada balita yang terintegrasi dalam kegiatan MTBS telah dibuat prosedur tetap untuk melakukan penilaian dan pengklasifikasian penyakit batuk atau kesukaran bernapas, pengobatan dan perawatannya serta cara pendidikan kesehatan pada ibu atau pengantarnya. ${ }^{3}$

Grafik angka kesakitan pneumonia dalam periode 3 tahun terakhir di tidak menunjukan perubahan. Tetapi jika dibandingkan dengan target nasional yang diharapkan (10/100 balita) ternyata angka kesakitan pneumonia di masih tinggi (15/100 balita). ${ }^{4}$ Sedangkan di Puskesmas Kedawung sebagai salah satupuskesmas yang berada di wilayah yang melaksanakan MTBS dengan jumlah balita tahun 2010 sebanyak 4722, tahun 2011 sebanyak 4657, kunjungan balita dengan kasus terbanyak adalah penyakit ISPA. ${ }^{4}$ Kasus penyakit ISPA pada balita dalam 2 tahun terakhir mengalami kenaikan dari $32 \%$ pada tahun 2009 menjadi $36,6 \%$ pada tahun 2010 begitu pula dengan kasus pneumonia dari 3,1\% pada tahun 2009 menjadi 4,2\% pada tahun 2010. ${ }^{4}$ Angka kesakitan penyakit pneumonia mengalami kenaikan tetapi kalau dibandingkan dengan target penemuan kasus (10\%) masih jauh dibawah target yang diharapkan padahal angka kesakitan ISPA tinggi. ${ }^{4}$

Berdasarkan hasil studi pendahuluan pada bulan Januari 2014 didapatkan data 10 balita yang menderita batuk dan 7 balita kesukaran bernapas mendapatkan pelayanan dengan pendekatan MTBS di ruang anak dengan baik,3 balita dalam pelaksanaannya masih ditemukan penanganan yang belum sesuai dengan prosedur tetap MTBS seperti dalam memeriksa atau menghitung pernapasan tidak 1 menit penuh, dalam menentukan tindakan untuk memberikan pengobatan/perawatan selalu menggunakan antibiotik, ketika memberikan konseling/pendidikan kesehatan pada ibu atau pengantar terlalu cepat, ibu/pengantar tidak diberi kartu nasihat ibu, pencatatan dan pelaporan yang belum rapih sehingga dalam memberikan tindak lanjut tidak dilakukan penggantian antibiotik. Dan dari wawancara dengan 6 orang ibu pengantar balita yang sakit batuk dan kesukaran bernapas yang berobat ke Puskesmas Kedawung Kabupaten Cirebon , pengantar/ibu-ibu balita tersebut tidak dapat menyebutkan tentang tanda bahaya umum, kapan ibu harus segera kembali membawa anaknya ke sarana tenaga kesehatan.

\section{METODE PENELITIAN}

Pada penelitian ini menggunakan metode deskriptif kuantitatif untuk mendapatkan suatu gambaran yang jelas mengenai penatalaksanaan penyakit ISPA pada balita dengan pendekatan MTBS yang dilakukan di Puskesmas Kedawung Kabupaten Cirebon .

Populasi dalam penelitian ini adalah hasil penatalaksanaan anak balita yang menderita ISPA yang berobat ke Puskesmas Kedawung Kabupaten Cirebon pada bulan Desember 2013 berjumlah 141 responden. Sampel yang diambil pada penelitian ini dengan cara accidental sampling dari kegiatan penatalaksanaan penyakit ISPA pada balita dengan pendekatan MTBS yang dilakukan di Ruang Anak Puskesmas Kedawung Kabupaten Cirebon yang di lakukan pada bulan Maret 2013 .

Pengumpulan data dengan cara melakukan pengamatan/observasi langsung nonpartisipatif dan studi dokumentasi terhadap penatalaksanaan penyakit ISPA pada balita dengan pendekatan MTBS yang dilakukan di Puskesmas Kedawung Kabupaten Cirebon . Dalam melakukan pengamatan ini peneliti tidak terlibat langsung dalam kegiatan. Dalam studi dokumentasi peneliti mengamati atau melihat catatan yang telah dibuat oleh petugas di lembar tata laksana balita sakit.

Pengamatan dilakukan pada semua balita yang mendapatkan penatalaksanaan MTBS di ruang MTBS (Balai Pengobatan Anak). 


\section{HASIL PENELITIAN}

\section{Penilaian Penyakit ISPA pada Balita}

Diagram 1. Kegiatan Menilai Penyakit ISPA pada Balita

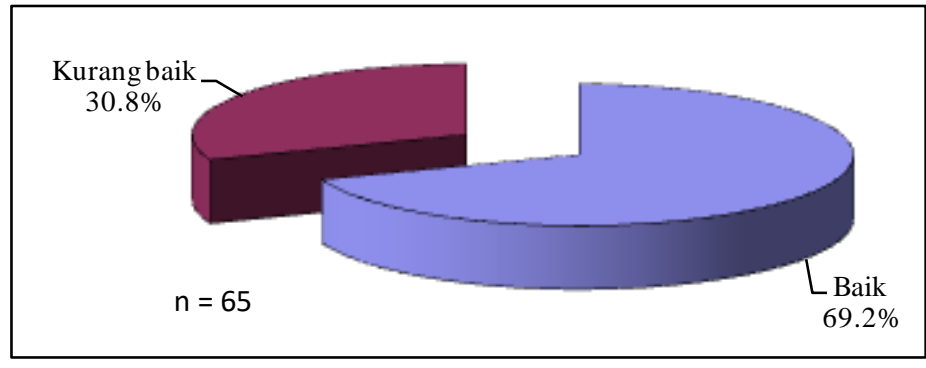

Berdasarkan standar dari Depkes RI maka pelaksanaan kegiatan menilaipenyakit ISPA padabalita yang dilakukan di PuskesmasKedawungKabupaten Cirebon masih kurang baik.

\section{Mengklasifikasikan Penyakit ISPA pada Balita}

Diagram 2. Kegiatan Mengklasifikasikan Penyakit ISPA pada Balita

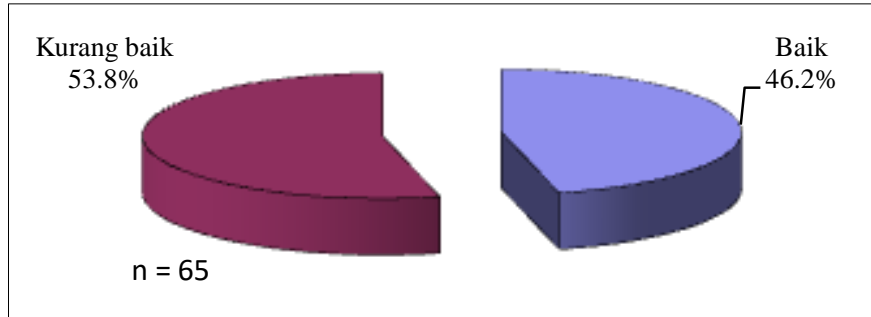

Berdasarkan standar dari Depkes RI maka pelaksanaan kegiatan mengklasifikasikan penyakit ISPA pada balita yang dilakukan di Puskesmas Kedawung Kabupaten Cirebon masih kurang baik.

\section{Menentukan Tindakan pada Balita yang Menderita ISPA}

Diagram 3. Kegiatan Menentukan Tindakan pada Balita dengan ISPA

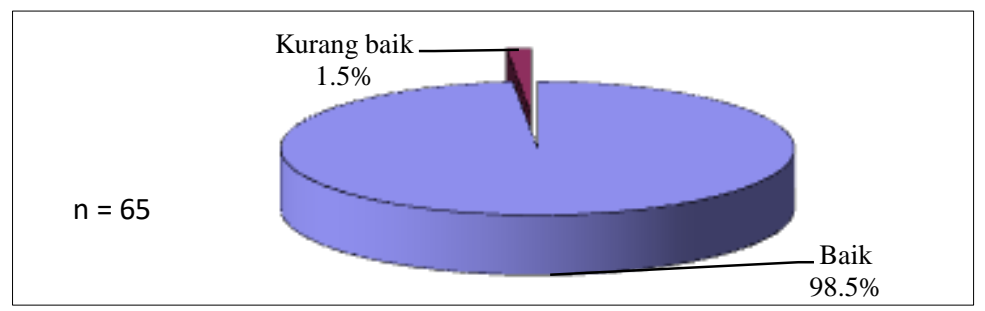

Berdasarkan standar dari Depkes RI maka pelaksanaan kegiatan menentukan tindakan pada balita dengan ISPA yang dilakukan oleh perawat di Puskesmas Kedawung Kabupaten Cirebon sudah baik. 


\section{Mengobati Balita yang Menderita Penyakit ISPA}

Diagram 4. Kegiatan Mengobati Balita yang Menderita ISPA

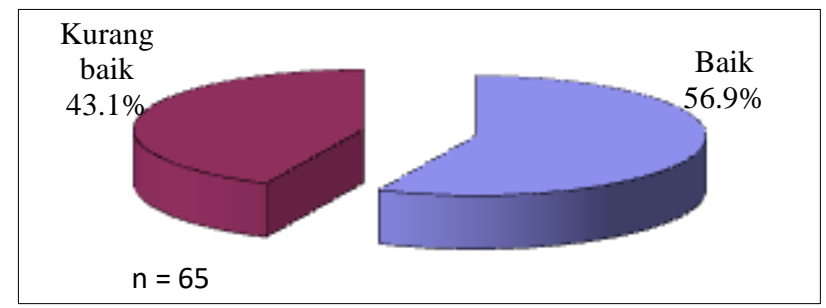

Berdasarkan standar dari Depkes RI maka kegiatan mengobati balita yang menderita penyakit batuk dan kesukaran bernafas /ISPA yang dilakukan di Puskesmas Kedawung Kabupaten Cirebon Tahun 2013 masih kurang baik.

\section{Konseling pada Ibu Balita}

Diagram 5. Kegiatan Konseling pada Ibu

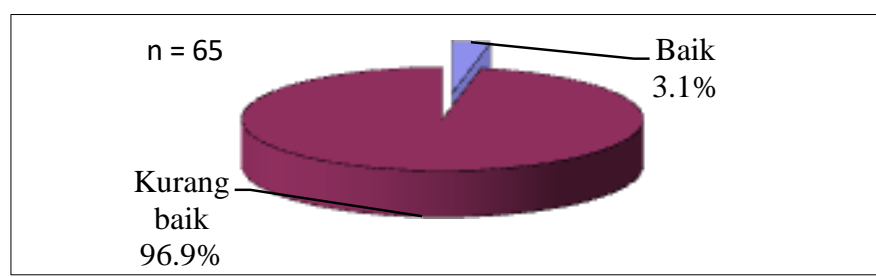

Berdasarkan standar Depkes RI maka kegiatan konseling pada ibu yang dilakukan di Puskesmas Kedawung Kabupaten Cirebon Tahun 2013 masih kurang baik.

\section{Tindak Lanjut pada Kasus Lama (Kunjungan Ulang)}

Diagram 6. Kegiatan tindak Lanjut yang Dilakukan

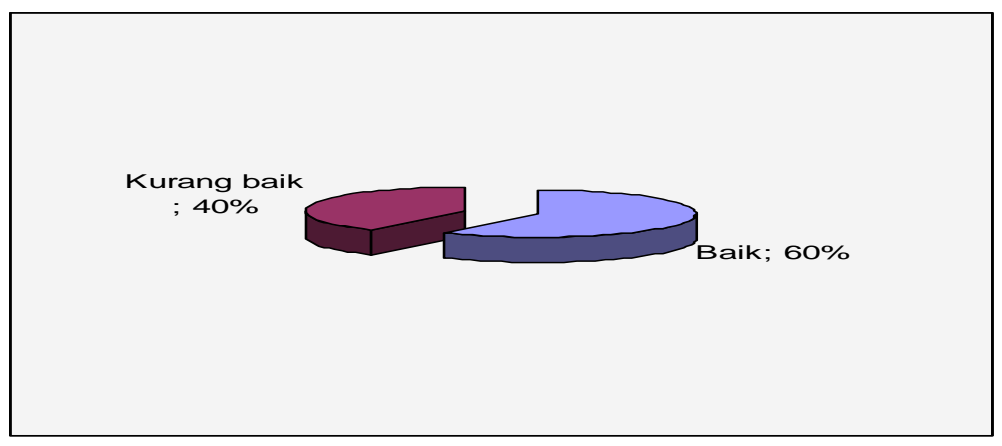

Berdasarkan skore perhitungan yang dilakukan pada 5 kegiatan tindak lanjut pada kasus kunjungan ulang dari yang seharusnya 15 kegiatan tindak lanjut didapatkan hasil sebagian besar kegiatan kurang baik (40\%) 


\section{PEMBAHASAN}

\section{Penyakit ISPA pada Balita}

Hasil penelitian terhadap kegiatan perawat dalam menilai penyakit ISPA pada balita yang dilakukan di Puskesmas Kedawung Kabupaten Cirebon didapatkan hasil bahwa kegiatan menilai penyakit ISPA pada balita 30,8\% kurang baik dan 69,2\% baik, angka ini menurut standar Depkes berarti menggambarkan pelaksanaan menilai penyakit ISPA kurang baik. Pada kegiatan menilai penyakit ISPA pada balita ini ada 7 aspek yang diamati, dari ke 7 aspek tersebut 5 aspek sudah baik sedangkan 2 aspek masih kurang baik. Aspek menanyakan dan mencatat kesulitan nafas balita dari 65 kegiatan hanya 42 (64,6\%) yang melakukan sedangkan $23(35,4 \%)$ tidak melakukan. Hal ini terjadi karena petugas menganggap bahwa cukup dengan melihat saja kondisi anak sehingga tidak menanyakan pada ibu balita. Pada aspek menanyakan dan mencatat kesulitan minum juga didapatkan hasil dilakukan $35(53,8 \%)$ dan $30(46,2 \%)$ tidak dilakukan. Hal ini mungkin dikarenakan petugas pada saat pemeriksaan melihat anak tersebut sedang menyusu. Untuk aspek yang lain sudah dilakukan $>80 \%$ berarti sudah baik.

Menurut Depkes RI untuk memberantas, mencegah meningkatnya angka kesakitan atau angka kematian balita yang disebabkan oleh infeksi sistem pernafasan salah satu upayanya adalah dengan mendeteksi secara dini penyakit ISPA. Jika kegiatan menilai masih kurang baik maka akan mengakibatkan kurang baik dalam mengklasifikasikan jenis penyakit ISPA yang diderita oleh balita. ${ }^{1}$

Petugas kesehatan dalam melakukan kegiatan penilaian ini harus memiliki kemampuan untuk berkomunikasi dengan ibu balita guna menggali data yang diperlukan untuk menilai penyakit ISPA pada balita.

\section{Mengklasifikasikan Penyakit ISPA pada Balita}

Hasil yang didapatkan tentang kegiatan mengklasifikasikan penyakit ISPA adalah 53,8\% masih kurang baik dan 46,1\% baik. Angka ini menurut standar Depkes berarti menggambarkan pelaksanaan mengklasifikasikan penyakit ISPA kurang baik.

Aspek yang diteliti pada kegiatan mengklasifikasikan penyakit ISPA pada balita aspek menghitung frekuensi nafas dalam 1 menit banyak tidak dilakukan, $36(55,3 \%)$ tidak dilakukan padahal tersedia soundtimer. Hal ini dikarenakan perawat menganggap sudah dapat mengetahui sesak nafas atau tidak dari inspeksi saja. Juga pada aspek mencatat pengklasifikasian sesuai hasil pemeriksaan banyak tidak dilakukan yaitu 36 (44,6\%). Hal ini dikarenakan petugas tersebut tidak melakukan perhitungan terhadap frekuensi nafas balita selama 1 menit. Sedangkan untuk 2 aspek yang lain sudah baik dilakukan petugas.

Petugas kesehatan dalam mengklasifikasikan penyakit ISPA pada balita harus melakukannya dengan cermat dan teliti juga diperlukan kesabaran serta harus berpedoman pada prosedur tetap bagan MTBS. ${ }^{2,3}$

Pengklasifikasian penyakit ISPA pada balita yang kurang baik akan dapat membingungkan petugas kesehatan itu sendiri dalam menentukan tindakan apakah pengobatan dengan antibiotik atau pengobatan tanpa antibiotik.

\section{Menentukan Tindakan pada Balita yang Menderita Penyakit ISPA}

Hasil yang didapatkan tentang kegiatan menentukan tindakan pada balita yang menderita ISPA adalah sudah baik $(98,5 \%)$. Petugas sudah bisa menentukan apakah balita tersebut dirujuk ke rumah sakit atau cukup diobati di puskesmas saja. Rujukan yang cepat dan tepat dapat mencegah kefatalan penyakit bahkan kematian. 
Tindakan dalam menentukan balita dirujuk ke rumah sakit atau tidak, seorang tenaga kesehatan harus paham dan tahu tentang tanda-tanda bahaya umum pada anak balita sakit dan pneumonia berat serta harus mempunyai kemampuan untuk meyakinkan pada ibu bahwa anaknya harus segera mendapatkan pertolongan di sarana kesehatan yang fasilitasnya lebih lengkap.

\section{Memberikan Pengobatan pada Balita yang Menderita Penyakit ISPA}

Hasil penelitian yang telah dilakukan menunjukkan bahwa kegiatan mengobati balita dengan penyakit ISPA adalah $43,1 \%$ kurang baik dan 56,9\% baik. Angka ini menurut standar Depkes menggambarkan pelaksanaan pengobatan penyakit ISPA balita kurang baik. Dalam memberikan pengobatan petugas kesehatan harus mengikuti prosedur tetap untuk pengobatan, baik jenis antibiotik, dosisnya dan lamanya.

Petugas kesehatan Puskesmas Kedawung Kabupaten Cirebon sebanyak $60 \%$ masih saja memberikan antibiotik pada kasus yang seharusnya tidak mendapatkan antibiotik dan kurang menganjurkan untuk menggunakan obat batuk tradisional yang aman untuk balita pada ibu. Hal ini mungkin dikarenakan pengklasifikasian yang kurang baik sehingga petugas langsung saja memberikan antibiotik, petugas juga tidak memikirkan akibat dari penggunaan antibiotik yang tidak sesuai /berlebihan. Disamping itu juga ibu balita sudah terlalu biasa menggunakan antibiotik untuk anaknya sehingga punya anggapan jika tidak memakai antibiotik maka anaknya tidak akan sembuh.

Kewenangan memberikan pengobatan termasuk pemberian antibiotika petugas di balai pengobatan oleh petugas yang bukan dokter karena adanya pendelegasian kewenangan oleh dokter kepada petugas. Padahal pemberian antibiotik yang tidak tepat pada balita maka dikhawatirkan anak akan mengalami resistensi terhadap antibiotika tersebut. Hasil Penelitian Ary Yunanto tahun 2001 diketahui resistensi bakteri penyebab pneumonia anak tertinggi adalah terhadap ampisilin (50\%), streptomisin + penisilin (39,7\%) dan kotrimoksazol $(14,1 \%) .{ }^{19}$ Juga akan membuat hal yang sia-sia karena walaupun tanpa antibiotika balita tersebut akan sembuh dengan sendirinya asalkan istirahat dan asupan gizi yang seimbang/ baik, cukup mendapatkan obat-obat simptomatis yang aman saja. ${ }^{5}$

\section{Konseling pada Ibu}

Hasil penelitian didapatkan bahwa kegiatan konseling yang dilakukan petugas adalah 96,9\% kurang baik dan 3,1\% baik. Angka ini menggambarkan pelaksanaan konseling kurang baik. Petugas hanya menginformasikan sedikit dari yang seharusnya disampaikan kepada ibu balita. Disamping karena jumlah kunjungan yang banyak juga karena ruang tunggu yang kurang luas. Penggunaan kartu nasihat ibu leaflet juga jarang digunakan. Hanya aspek menjelaskan tanda bahaya umum dan aspek kapan harus kembali yang sudah baik $(>80 \%)$ sedangkan untuk aspek yang lain mengenai gizi, perawatan, pencegahan dan pengobatan penyakit ISPA masih kurang baik $(<80 \%)$.

Konseling pada ibu ini sangat penting dalam pemberantasan penyakit menular. Dengan konseling yang baik diharapkan ibu dapat merawat dan mengenal penyakit batuk dengan kesukaran bernafas pada anak balita sehingga ibu dapat melakukan tindakan pencegahan dan tidak terlambat membawa anak balitanya yang sakit ke sarana kesehatan / tenaga kesehatan untuk berobat sehingga kematian atau bertambah parahnya balita dapat dihindari juga akan mengurangi resiko penularan pada balita lain. ${ }^{2}$

Hasil penelitian Haman Hadi pada tahun 2001 di Kabupaten Kebumen menyimpulkan bahwa konseling gizi mempunyai pengaruh positif terhadap status gizi balita penderita ISPA sehingga dapat mempercepat proses penyembuhannya. Hal ini sesuai dengan penelitian di 
Kabupaten Tapin Kalimantan Selatan oleh Dina Angelika pada tahun 2003 yang menyimpulkan bahwa pemberian modisco (Modified Disco 150) pada balita yang menderita penyakit ISPA dapat mempercepat kesembuhannya. ${ }^{6}$

\section{Tindak Lanjut}

Pada penelitian ini kegiatan tindak lanjut di puskesmas tidak dapat diidentifikasi secara utuh karena dari 15 kasus yang diharuskan kunjungan ulang hanya 5 kasus yang datang selebihnya tidak datang. Dari kelima kasus tersebut sudah dilakukan tindak lanjut dengan baik (>80 \%). Penilaian ulang dilakukan dan pemberian antibiotik sudah sesuai dengan standar pengobatan.

Menurut Depkes jika balita sakit yang seharusnya melakukan kunjungan ulang tetapi tidak datang maka harus dilakukan kunjungan rumah untuk mengetahui hasil pengobatan dan perkembangan kondisi balita. Di Puskesmas Kedawung Kabupaten Cirebon kunjungan rumah tidak dilakukan sehingga hasil pengobatan dan kondisi balita tidak diketahui. Hal ini mungkin karena kurang kerja sama lintas program terutama PHN Perkesmas. Disamping itu juga adanya kendala dalam sarana dan biaya transportasi yang terlalu rumit untuk penggantiannya, juga bedanya rencana kerja yang terjadwal dari petugas.

\section{SIMPULAN}

1. Kegiatan penilaian penyakit ISPA pada balita yang dilakukan di Puskesmas Kedawung Kabupaten Cirebon tahun 2013 didapatkan hasil kurang baik

2. Kegiatan mengklasifikasikan penyakit ISPA pada balita yang dilakukan di Puskesmas Kedawung Kabupaten Cirebon tahun 2013 didapatkan hasil kurang baik

3. Kegiatan untuk menentukan tindakan yang harus dilaksanakan pada balita yang menderita penyakit ISPA di Puskesmas Kedawung Kabupaten Cirebon tahun 2013 sudah baik

4. Kegiatan mengobati balita yang menderita penyakit ISPA yang dilakukan di Puskesmas Kedawung Kabupaten Cirebon tahun 2013 didapatkan hasil kurang baik.

5. Kegiatan memberikan konseling pada ibu balita / pengantar yang dilakukan di Puskesmas Kedawung Kabupaten Cirebon tahun 2013 didapatkan hasil kurang baik.

6. Kegiatan memberikan tindak lanjut pada kasus yang harus datang / melakukan kunjungan ulang tetapi tidak datang, tidak dilakukan kunjungan rumah berarti tindak lanjut yang diberikan oleh petugas kesehatan di Puskesmas Kedawung Kabupaten Cirebon tahun 2013 masih kurang.

\section{SARAN}

Hasil kegiatan penatalaksanaan penyakit ISPA pada balita dengan pendekatan MTBS di Puskesmas Kedawung Kabupaten Cirebon masih kurang baik maka dengan segala keterbatasan dan kekurangannya peneliti memberi saran sebagai berikut :

1. Bagi Institusi Pendidikan

Hasil penelitian ini agar dapat di jadikan bahan masukan dalam kebijakan program dan bahan ajar bagi mahasiswa

2. Bagi Peneliti Lain

Hasil penelitian ini dapat di jadikan sebagai referensi dalam penelitian lanjutan sehingga di harapkan hasil penelitian pada bidang yang sama dapat lebih baik hasilnya.

3. Bagi Puskesmas Kedawung 
1) Menambah jumlah petugas yang sudah dilatih MTBS untuk bertugas di ruang MTBS.

2) Meningkatkan koordinasi dengan dinas kesehatan kabupaten untuk pemenuhan sarana MTBS dan pemecahan masalah dalam pelaksanaan MTBS.

3) Perlu adanya monitoring dan evaluasi secara berkala terhadap pelaksanaan MTBS oleh Kepala Puskesmas.

4) Memperluas ruangan MTBS.

5) Mempermudah penggantian biaya kunjungan rumah.

4. Bagi Petugas Kesehatan

1) Jangan terlalu yakin dengan penglihatan tetapi harus dilakukan konfirmasi dan validasi data.

2) Harus memikirkan efek samping dari pemberian antibiotika yang tidak perlu pada balita.

3) Mau meningkatkan kegiatan sesuai standar/bagan MTBS yang ada.

4) Meningkatkan kerjasama lintas program dan membuat jadwal rencana kerja harian.

\section{DAFTAR PUSTAKA}

1. Depkes RI. Pedoman pemberantasan penyakit ISPA untuk penenggulangan pada balita. Jakarta:Depkes RI;2003

2. Ditjen P2M \& Litbang Depkes RI. Kajian riset operasional intensifikasi pemberantasan penyakit menular tahun 1999 - 2003. Jakarta:Ditjen P2M;2004

3. Depkes RI. Bagan managemen terpadu balita sakit.Jakarta:Depkes RI;2001.

4. Anonim.Profil Dinas Kesehatan Kabupaten Cirebon:Cirebon;2013.

5. Nelson. Ilmu kesehatan anak volume 2. Edisi 15. Jakarta:EGC;2003.

6. Depkes RI. Visi,Misi Indonesia Sehat 2010:Jakarta;2003. 